\title{
Kajian Strategi Aplikasi Material Kayu Bekas pada Elemen Desain Interior Restoran di Bandung
}

\author{
Tiara I.W. Primadani ${ }^{1}$, Dwinita Larasati ${ }^{2}$, Budi Isdianto ${ }^{3}$ \\ ${ }^{1}$ Institut Teknologi Kreatif Bina Nusantara Malang, ${ }^{2,3}$ Institut Teknologi Bandung \\ ${ }^{1}$ tiara.primadani@gmail.com, ${ }^{2}$ titalarasati@gmail.com, ${ }^{3}$ budis@lppm.itb.ac.id
}

\begin{abstract}
ABSTRAK
Desain Interior sangat berperan dalam menjaga keharmonisan antara manusia dan lingkungan melalui desain eko-interior. Karakteristik fisik dari desain eko-interior mudah ditemukan dalam aplikasi material ramah lingkungan seperti material kayu bekas yang digunakan kembali pada elemen interior. Beberapa restoran di Bandung telah menerapkan penggunaan kembali material kayu bekas dalam elemen interiornya. Penelitian ini bertujuan untuk mengidentifikasi strategi dan tingkat terapan penggunaan kembali material kayu bekas yang diterapkan oleh desainer sebagai elemen interior restoran. Metode penelitian yang digunakan adalah kualitatif-deskriptif. Hasil dari penelitian ini diukur dengan metode ukur DCBA menunjukkan bahwa tingkat terapan aplikasi material kayu bekas pada elemen interior restoran di Bandung masih dalam kategori "Terapan Umum” dan "Upaya Ringan" belum mencapai situasi ideal eko-interior.
\end{abstract}

Kata kunci: eko-interior; restoran; digunakan kembali; material; kayu

\section{ABSTRACT}

Interior designers play a role in bringing together the harmony between humans and the environment through eco-interior design. Physical characteristics of eco-design interior are easily found in the application of eco-materials such as reused wood materials on interior elements. There are several restaurants in Bandung that has applied reused wood materials in their interior elements. This research is aimed to identify strategies and applied category of reused wood material applied by designers to the interiors of a restaurant. The method used in this research is a qualitative-descriptive and DCBA measure method. The results of this study show that the application level of used wood materials on restaurant interior elements in Bandung is still in the category "General Applied" and "Light Efforts" have not reached the ideal eco-interior situation.

Keyword: eco-interior; restaurant; reused; material; wood

\section{PENDAHULUAN}

Kemajuan industri yang semakin pesat saat ini mengakibatkan gaya hidup masyarakat urban terus berkembang. Perkembangan itu ditandai dengan kemunculan berbagai produk yang silih berganti mengikuti tren, akibatnya umur pakai suatu barang akan menjadi lebih pendek. Habisnya umur pakai barang bukan karena rusak, namun bisa juga karena tidak sesuai dengan perkembangan tren yang berlaku. Produk yang sudah tidak lagi sesuai tren akibat perkembangan gaya yang begitu cepat pada masyarakat urban akan menjadi sampah yang berbahaya bagi lingkungan jika tidak diperpanjang masa pakainya. Salah satu cara memanfaatkan produk yang kehilangan masa pakainya yaitu dimanfaatkan kembali sebagai elemen interior.

Desainer Interior tidak hanya sebagai inovator gaya tetapi juga menjadi pemecah masalah, sehingga diharapkan desainer dapat menciptakan desain yang mempertimbangkan dampaknya terhadap lingkungan. Salah satu peran serta desainer interior dalam gerakan peduli lingkungan adalah mengaplikasikan material bekas pada elemen interior restoran. Menurut Hidayat, Fahmahwaty (2011) dan Calkins (2009), aplikasi material bekas pada elemen interior restoran 
Tiara I.W. Primadani, Dwinita Larasati, Budi Isdianto

Kajian Strategi Aplikasi Material Kayu Bekas pada Elemen Desain Interior Restoran di Bandung

merupakan salah satu upaya dalam menciptakan desain ramah lingkungan yang merupakan strategi untuk mencapai desain berkelanjutan. Terdapat beberapa restoran di Bandung yang telah mengaplikasikan material bekas pada elemen interiornya. Aplikasi material bekas pada interior restoran menjadi salah satu jalan keluar mengatasi permasalahan lingkungan di Bandung.

Restoran dan café dengan desain interior eco-style juga banyak ditemui di Bandung. Pada restoran tersebut terdapat beberapa elemen interiornya menggunakan material bekas, padahal desain interior restoran menurut Kusumawidagdo (2005) dan Lawson (1973) berfungsi sebagai media informasi menu yang disediakan, jenis pelayanannya dan citra restoran. Bukan berarti restoran yang mengaplikasikan material bekas pada elemen interiornya menginformasikan bahwa makanan yang disediakan juga berasal dari bahan bekas, karena aplikasi material bekas tersebut bertujuan untuk membangun ciri khas desain interior restoran yang berbeda dengan restoran lainnya sebagai strategi pemasaran. Selain sebagai salah satu upaya kepedulian lingkungan, aplikasi material bekas pada elemen interior restoran tersebut dimaksudkan untuk mengikuti tren eco-style dan memberikan pengalaman tersendiri bagi pengunjungnya.

\section{METODE PENELITIAN}

Metode penelitian yang digunakan adalah metode kualitatif - deskriptif. Analisis deskriptif digunakan untuk mendeskripsikan strategi aplikasi material bekas pada elemen interior restoran berdasarkan prinsip desain eko-interior. Strategi aplikasi material bekas pada elemen interior restoran di Bandung diukur dengan metode DCBA untuk mengetahui tingkat upaya terapan dan potensinya sebagai desain eko-interior.

\section{HASIL PENELITIAN DAN PEMBAHASAN}

\section{A. Pendekatan Teori}

\section{Material Bekas sebagai Upaya Mencapai Desain Eko-Interior}

Desainer dan konsumen menggantungkan pada material bangunan untuk membuat dan mengkondisikan suatu ruang dimana kita tinggal dan beraktifitas. Pemilihan material pada berbagai macam komponen dalam desain interior sangat penting untuk membentuk suasana ruang interior tertentu (Pile, 2003 dalam Kang, Guerin, 2009). Material yang diaplikasikan pada desain interior restoran tidak bisa dilakukan secara sembarangan. Karena berhubungan dengan nafsu makan dan kesehatan tubuh, aktifitas makan sangat memperhatikan kebersihan makanan dan kenyamanan lingkungan sekitarnya. Material yang diaplikasikan pada elemen interior restoran harus mempunyai nilai estetika karena dapat mempengaruhi kenyamanan pengunjung saat berada di dalam restoran. Menurut Pile dalam Maximilian (2013) material mempunyai dua kriteria yaitu aspek fungsional dan visual. Aspek fungsional material berdasarkan karakter dan kekuatannya sebagai elemen interior pembentuk ruang, mempunyai kemampuan insulasi termal dan bunyi untuk kenyamanan lingkungan. Aspek visual material adalah estetika yang berperan sebagai pembentuk suasana ruang yang ingin ditampilkan. Liu dan Jang dalam Wardono (2011) berpendapat bahwa semua fitur lingkungan dari sebuah desain interior restoran, yang berwujud atau tidak berwujud memberikan dampak yang signifikan terhadap respon-respon psikologis pengunjung. Respon psikologis tersebut akan mempengaruhi emosional pengunjung yang mana menurut Kusumawidagdo (2005) keadaan emosional akan membuat dua perasaan yang dominan yaitu perasaan senang dan membangkitkan keinginan, baik yang muncul dari psikologikal set ataupun keinginan yang bersifat mendadak (impulse). Aspek pembentuk suasana ruang berpengaruh signifikan pada kesenangan pelanggan, khususnya suasana yang memberikan dampak signifikan terhadap gairah pelanggan saat berada di dalam restoran (Kusumawidagdo, 2005). 


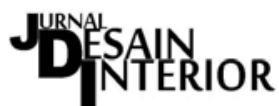

Vol. 4, No. 1, Juni 2019, pISSN 2527-2853, eISSN 2549-2985

Material merupakan salah satu elemen penting dalam desain yang berpengaruh pada keberlanjutan dalam lingkungan interior. Untuk menciptakan desain interior berkelanjutan penggunaan material interior yang berwawasan ekologi sangat penting untuk mengurangi aliran sumber daya tak terbarukan menjadi material interior dan menjadi polusi sepanjang siklus bahan interior tersebut (Kim, 1998 dalam Kang, Guerin, 2009). Bangunan interior dibentuk dari material, produk dan sistem yang saling berhubungan dari material bangunan dari seluruh dunia (Childs, Argeles, Henderson, Horst, \& Malin, 2006). Pemilihan material yang ramah lingkungan sangat sangat penting karena menurut Working Group on Sustainable Construction (WGSC) pada tahun 2004, menetapkan bahwa 50\% dari energi dan bahan-bahan yang diproduksi dari sumber daya bumi digunakan oleh sektor bangunan di dunia (Ayalp, 2012). Berdasarkan kajian literatur dari Bonda dan Sosnowchik (2007), Aktas (2013), Pilatowicz (1995) dan GBCI (2014), material bekas termasuk dalam material yang mempunyai dampak lingkungan rendah karena aplikasi material bekas dapat mengurangi eksploitasi sumber daya alam, mempunyai embodied energy yang rendah karena tidak melewati proses manufaktur dan mengurangi terjadinya sampah.

\section{Material Kayu Bekas}

Indonesia merupakan sebagai salah satu negara tropis di dunia dan memiliki sumber daya kayu dari pohon di hutan alam maupun hutan tanaman yang melimpah, namun karena tata kelola hutan yang masih buruk menyebabkan semakin terbatasnya produksi kayu. Apalagi kayu tidak hanya digunakan di bidang konstruksi saja, namun juga untuk bidang industri kertas, alat transportasi (perahu), assesoris dan bahan bakar. Masa tumbuh kayu hingga bisa dimanfaatkan untuk industri adalah minimal 5 tahun, sehingga jika pengusaha kayu tidak melakukan manajemen pelestarian hutan yang berwawasan lingkungan semakin menjadikan kayu menjadi barang eksklusif dan mahal. Bangunan yang mengaplikasikan material kayu dinilai tidak raman lingkungan karena dianggap ikut berperan dalam merusak hutan, padahal material kayu merupakan material yang tergolong ramah lingkungan dibandingkan beton dan logam (Purnomo, 2013).

Material kayu bekas diantaranya berasal dari bongkaran rumah tua, bekas bantalan rel kereta api, perahu kayu, kemasan/peti kemas, sedangkan material limbah kayu berasal dari industri pengolahan kayu. Material kayu bekas dapat dimanfaatkan kembali sebagai mana fungsi sebelumnya atau diolah untuk fungsi baru, contohnya kayu bekas struktur rumah dapat dimanfaatkan kembali sebagai struktur bangunan baru atau diolah menjadi finishing lantai, dinding, plafon, furnitur dan assesoris rumah/elemen estetis.

\section{Tabel Pengukuran DCBA Material Bekas sebagai Eko-Material}

Pada penelitian ini, parameter pada tiap klasifikasi DCBA disesuaikan dengan kondisi ideal dalam koteks desain berwawasan ekologi di Indonesia yang memungkinkan diterapkan di restoran-restoran di Bandung. Aspek-aspek yang menjadi variabel ukur DCBA dan kriteria klasifikasi tingkat aplikasi material bekas berdasarkan prinsip desain eko-interior berdasarkan kajian pustaka material berwawasan ekologi. Kriteria tingkat klasifikasi eko-material berdasarkan kebutuhan bahan baku baru, dampak sampah dan polusi yang ditimbulkan.

1. Kondisi 'D' pada “Terapan Umum”, merupakan situasi konvensional, pemilihan material tanpa pertimbangan eksploitasi SDA, sampah dan polusi yang membahayakan lingkungan, namun hanya berdasarkan tujuan estetika (indah), mudah didapatkan dan dipasang, harga murah. 
Tiara I.W. Primadani, Dwinita Larasati, Budi Isdianto

Kajian Strategi Aplikasi Material Kayu Bekas pada Elemen Desain Interior Restoran di Bandung

2. Kondisi 'C' pada “Upaya Ringan”, merupakan situasi yang mulai ada pertimbangan ekologi dalam memilih material namun belum signifikan. Upaya yang dilakukan dengan meminimalisir penggunaan material dan dampak negatif yang ditimbulkan terhadap lingkungan pada terapan umum.

3. Kondisi 'D' pada “Upaya Situasi Ideal”, merupakan situasi yang sudah berupaya memasukkan pertimbangan ekologi dalam memilih material yang menghasilkan dampak negatif pada lingkungan yang kecil, memilih material yang tidak mengeksploitasi SDA dan meminimalisir terjadinya sampah dan polusi yang membahayakan lingkungan.

4. Kondisi 'A' pada "Situasi Ideal”, merupakan situasi yang menerapkan prinsip desain ekointerior pada pemilihan materialnya yaitu dengan tidak mengeksploitasi SDA dan meminimalisir dampak negatif terhadap lingkungan hingga mendekati nol karena sampah dan polusi yang ditimbulkan.

Berdasarkan analisis dari studi kasus restoran yang mengaplikasikan material bekas dan kajian parameter DCBA menurut Larasati (2006) dan Kusumarini (2007), berikut tabel pengukuran DCBA dengan kriteria tingkatan terapan material bekas sebagai eko-material berdasarkan aspek siklus hidupnya.

Tabel 1. Pengukuran DCBA Material Bekas sebagai Eko-Material

\begin{tabular}{|c|c|c|c|c|}
\hline ASPEK & $\begin{array}{c}\text { D } \\
\text { TERAPAN UMUM }\end{array}$ & $\begin{array}{c}\text { C } \\
\text { UPAYA RINGAN }\end{array}$ & $\begin{array}{c}\text { B } \\
\text { UPAYA SITUASI } \\
\text { IDEAL }\end{array}$ & $\begin{array}{c}\text { A } \\
\text { SITUASI IDEAL }\end{array}$ \\
\hline $\begin{array}{l}\text { Pemilihan } \\
\text { Material }\end{array}$ & $\begin{array}{l}\text { Mengejar murah, mudah, } \\
\text { indah, tanpa } \\
\text { pertimbangan keterkaitan } \\
\text { ekologis. } \\
\text { (Kusumarini, 2007) }\end{array}$ & $\begin{array}{l}\text { Minimalisasi penggunaan } \\
\text { umum. }\end{array}$ & $\begin{array}{l}\text { Degradable material. } \\
\text { Menggunakan kayu } \\
\text { dan batu alam. } \\
\text { (Kusumarini, 2007) }\end{array}$ & $\begin{array}{l}\text { Mengurangi } \\
\text { eksploitasi sumber } \\
\text { daya alam dengan } \\
\text { material yang } \\
\text { bersifat recycled atau } \\
\text { reused. }\end{array}$ \\
\hline Bahan Baku & $\begin{array}{l}\text { Berasal dari bahan baku } \\
\text { yang tidak dapat } \\
\text { diperbarui. }\end{array}$ & $\begin{array}{l}\text { Berasal dari bahan baku } \\
\text { yang dapat diperbarui. }\end{array}$ & $\begin{array}{l}\text { Berasal dari material } \\
\text { recycled. }\end{array}$ & $\begin{array}{l}\text { Berasal dari material } \\
\text { reused. }\end{array}$ \\
\hline Finishing & $\begin{array}{l}\text { Penggunaan bahan-bahan } \\
\text { finishing kimia, tanpa } \\
\text { perhatian pada dampak. } \\
\text { (Kusumarini, 2007) }\end{array}$ & $\begin{array}{l}\text { Meminimalisasi } \\
\text { penggunaan finishing } \\
\text { kimia yang berdampak } \\
\text { polusi. } \\
\text { (Kusumarini, 2007) }\end{array}$ & $\begin{array}{l}\text { Menggunakan finishing } \\
\text { kimia yang berdampak } \\
\text { polusi rendah (product } \\
\text { selection). } \\
\text { (Kusumarini, 2007) }\end{array}$ & $\begin{array}{l}\text { Hanya menggunakan } \\
\text { bahan finishing alami } \\
\text { dan tidak berdampak } \\
\text { polusi. } \\
\text { (Kusumarini, 2007) }\end{array}$ \\
\hline $\begin{array}{l}\text { Lokasi Material } \\
\text { Diperoleh }\end{array}$ & $\begin{array}{l}\text { Material yang bahan } \\
\text { bakunya diimpor. }\end{array}$ & $\begin{array}{l}\text { Material yang bahan } \\
\text { baku dan proses } \\
\text { produksinya berada } \\
\text { dalam radius } 1000 \mathrm{~km} \\
\text { dari proyek atau masih } \\
\text { dalam wilayah Republik } \\
\text { Indonesia. }\end{array}$ & $\begin{array}{l}\text { Material yang bahan } \\
\text { baku dan proses } \\
\text { produksinya masih } \\
\text { berada dalam radius } \\
500 \mathrm{~km} \text { dari proyek. }\end{array}$ & $\begin{array}{l}\text { Material yang bahan } \\
\text { baku dan proses } \\
\text { produksinya masih } \\
\text { berada dalam radius } \\
50 \mathrm{~km} \text { dari proyek. }\end{array}$ \\
\hline Pemasangan & $\begin{array}{l}\text { Menggunakan bahan } \\
\text { tambahan yang } \\
\text { menimbulkan polusi } \\
\text { udara di dalam ruangan. } \\
\text { (lem) }\end{array}$ & $\begin{array}{l}\text { Meminimalisir } \\
\text { penggunaan bahan } \\
\text { tambahan yang } \\
\text { menimbulkan polusi } \\
\text { udara. (kombinasi lem } \\
\text { dan paku) }\end{array}$ & $\begin{array}{l}\text { Menggunakan bahan } \\
\text { tambahan yang tidak } \\
\text { menimbulkan polusi } \\
\text { udara di dalam } \\
\text { ruangan. (paku) }\end{array}$ & $\begin{array}{l}\text { Menggunakan teknik } \\
\text { kuncian, tanpa } \\
\text { tambahan bahan lain. }\end{array}$ \\
\hline Perawatan & $\begin{array}{l}\text { Penggunaan bahan-bahan } \\
\text { pembersih komersial dan } \\
\text { berkimia. } \\
\text { (Kusumarini, 2007) }\end{array}$ & $\begin{array}{l}\text { Meminimalisasi } \\
\text { penggunaan bahan } \\
\text { pembersih kimia. } \\
\text { (Kusumarini, 2007) }\end{array}$ & $\begin{array}{l}\text { Menggunakan bahan } \\
\text { pembersih alami. } \\
\text { (Kusumarini, 2007) }\end{array}$ & $\begin{array}{l}\text { Menggunakan bahan } \\
\text { pembersih alami } \\
\text { secara mandiri (self } \\
\text { produce). } \\
\text { (Kusumarini, 2007) }\end{array}$ \\
\hline $\begin{array}{l}\text { Akhir Masa } \\
\text { Pakai }\end{array}$ & $\begin{array}{l}\text { Material sekali pakai dan } \\
\text { memerlukan tempat } \\
\text { pembuangan khusus. }\end{array}$ & $\begin{array}{l}\text { Material sekali pakai dan } \\
\text { berakhir di TPA. }\end{array}$ & $\begin{array}{l}\text { Material yang dapat } \\
\text { digunakan kembali } \\
\text { setelah di daur ulang. }\end{array}$ & $\begin{array}{l}\text { Material yang dapat } \\
\text { digunakan kembali } \\
\text { tanpa di daur ulang. }\end{array}$ \\
\hline
\end{tabular}

Sumber: Modifikasi dari Kusumarini (2007) dan Larasati (2006). 


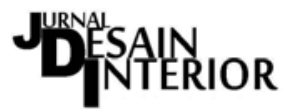

Vol. 4, No. 1, Juni 2019, pISSN 2527-2853, eISSN 2549-2985

\section{Deskripsi Obyek Kajian}

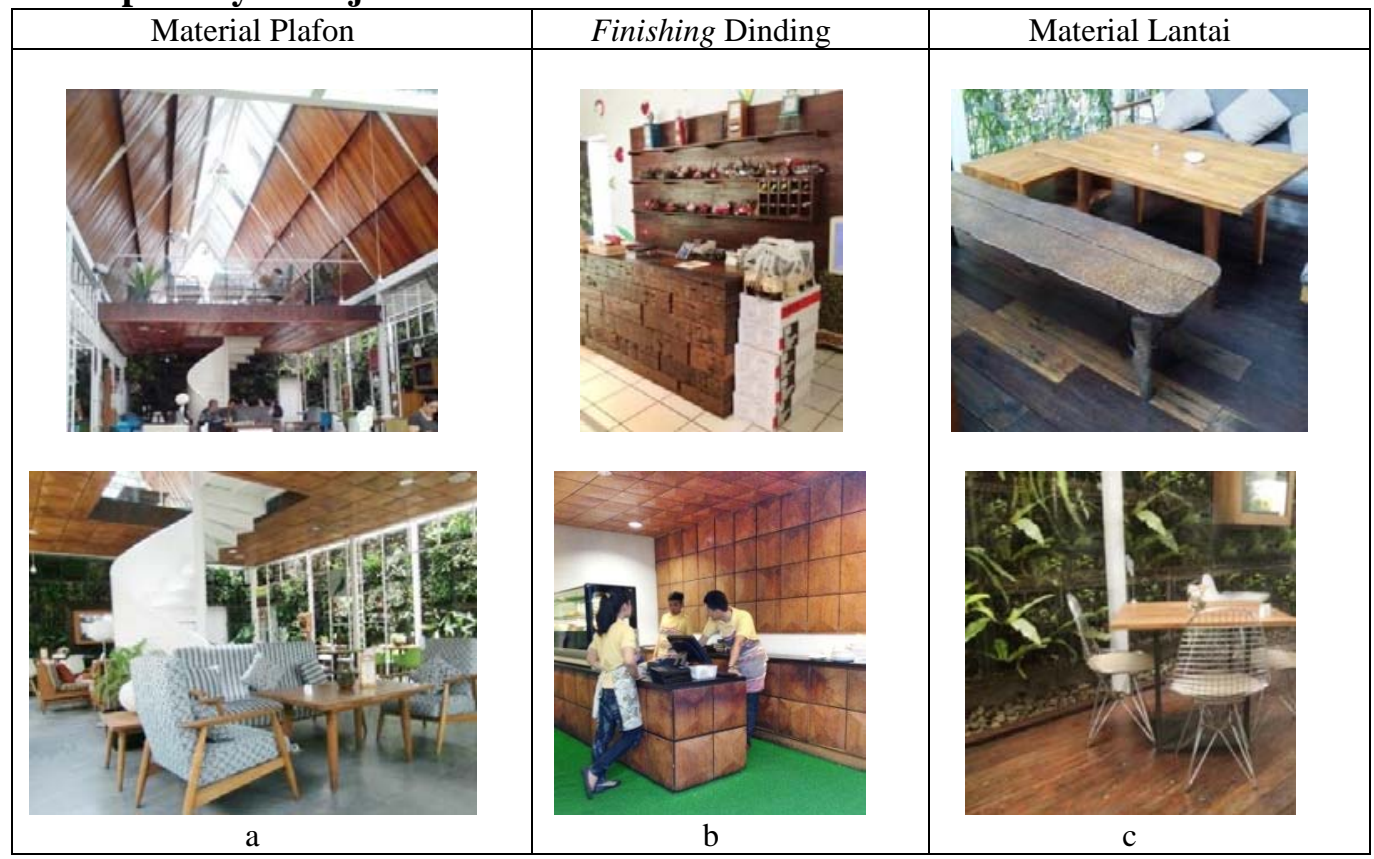

Gambar 1. Aplikasi Material Kayu Bekas sebagai Elemen Interior di Restoran A Sumber: Origin House \& Kitchen (2014)

Obyek kajian aplikasi material kayu bekas pada elemen interior restauran di Bandung yang pertama adalah restoran A. Restoran A merupakan sebuah restoran sekaligus sebuah toko retail yang menjual makanan organik dan perlengkapan rumah tangga. Bangunan restoran A terdiri dari dua masa yaitu bangunan rumah tua (eksisting) yang digunakan sebagai toko dan bangunan tambahan baru di belakangnya sebagai restoran. Tema desain interior restoran A adalah kembali ke alam dengan "green concept”. Berdasarkan Falrisya (2012), restoran A bernama 'Origin' yang memiliki makna "kembali ke asal atau kembali ke alam”, sehingga restoran ini didirikan untuk mengajak konsumennya bergaya hidup sehat dengan kembali ke alam, mengkonsumsi makanan- makanan yang sehat dan menggunakan produk yang mengacu pada konsep ekologis. Tema "kembali ke alam" pada restoran A dapat terlihat dari pemakaian warna hijau yang digunakan pada sebagian restoran ini, karena warna hijau merupakan warna yang dapat mewakili alam, dan aplikasi material alami seperti kayu dan batu. Menurut arsitek restoran A, nuansa warna hijau dan material alami digunakan pada beberapa bagian elemen interior untuk mencoba mengembalikan rasa sayang terhadap alam, rasa nyaman bersentuhan dengan alam dan mensyukuri keindahan alam (Falrisya, 2012). Konsep 'green' ekologi dicapai dengan aplikasi material bekas pada sebagian elemen interior seperti lantai, dinding, plafon. Material kayu bekas yang dimanfaatkan kembali diantaranya adalah kayu bekas bantalan rel kereta api, kayu jati dari bongkaran rumah tua dan limbah kayu potongan. Material yang digunakan dalam membangun Origin ini kurang lebih 40\% adalah material bekas (Falrisya, 2012).

Obyek kajian kedua adalah restoran B yang merupakan bangunan tunggal dua lantai yang dibagi menjadi tiga bagian area, yaitu area makan semi terbuka di lantai 1, area makan di dalam ruangan di lantai 1 dan area makan di dalam di lantai 2. Tema yang diusung restoran B adalah urban industrial. Untuk membentuk tema Urban industrial, desainer interior menggunakan daun jendela krepyak sebagai fasad, plafon, finishing dinding. Selain itu finishing unfinish juga terlihat pada beberapa bagian elemen interiornya. Fasad bangunan restoran B memanfaatkan 
kayu bekas daun jendela rumah tua yang berbentuk krepyak disusun vertikal serta vertical garden. Kayu bekas berbentuk krepyak juga diaplikasikan pada dinding di sebagian besar bangunan restoran B dan sebagai material plafon. Prosentase material bekas yang di aplikasikan di desain interior restoran $\mathrm{B} \pm 30 \%$. Material kayu bekas yang diaplikasikan di interior restoran $\mathrm{B}$ adalah kayu bekas daun jendela rumah tua yang berbentuk krepyak, daun pintu, kayu bekas bangunan rumah tua dan limbah potongan kayu.

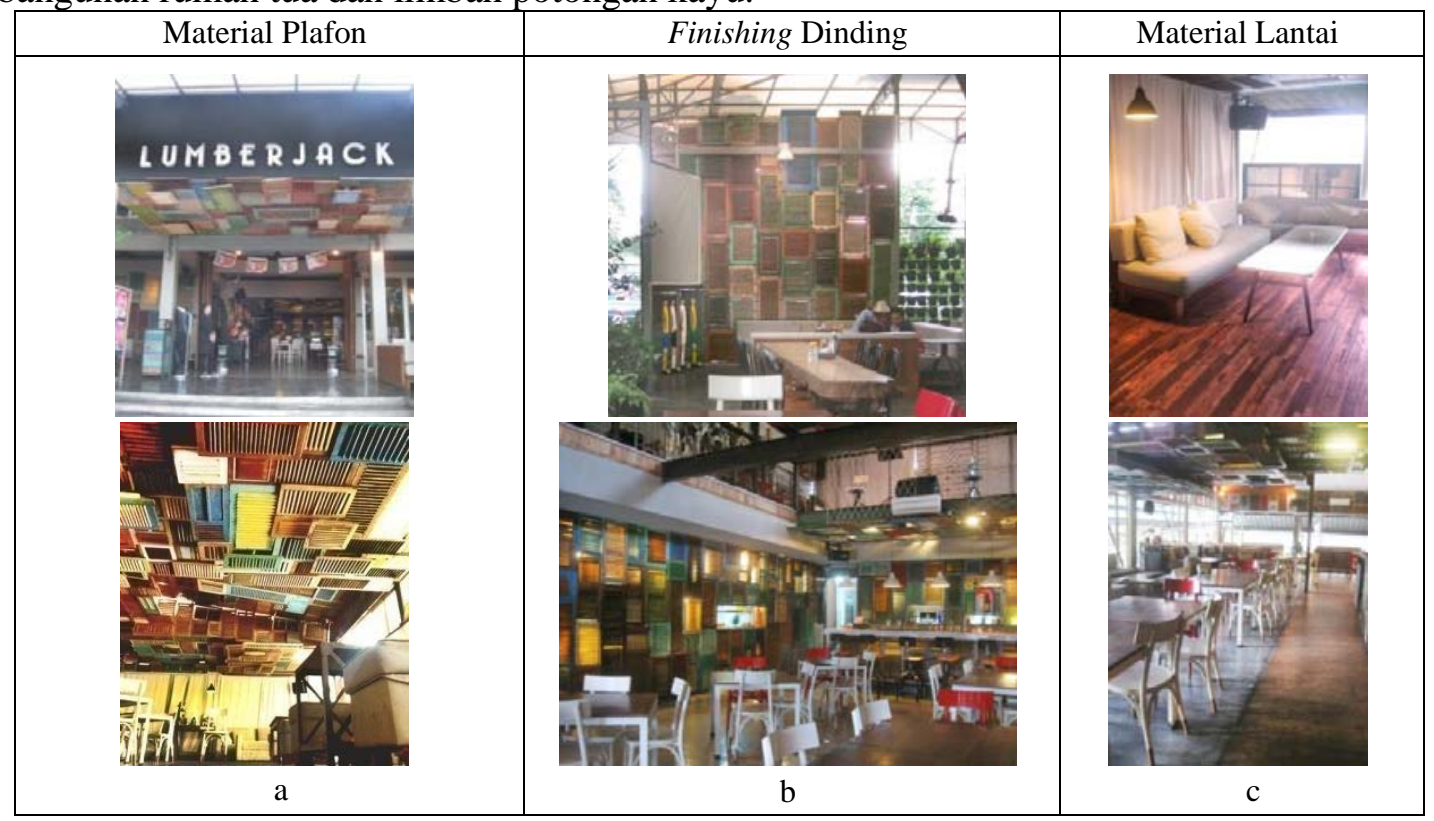

Gambar 2. Aplikasi Material Kayu Bekas sebagai Elemen Interior di Restoran B Sumber: Lumberjack Resto\& Bar (2014)

\section{B. Pembahasan}

\section{Strategi Aplikasi Material Kayu Bekas pada Restoran A}

Arsitektur dan desain interior restoran A dibangun berpedoman pada konsep 'green' untuk mencapai tema "kembali ke alam" dengan menghadirkan unsur-unsur alam ke dalam interiornya seperti pemakaian material kayu, tanaman dan warna-warna alam seperti hijau, coklat dan hitam. Material kayu yang digunakan adalah kayu bekas bantalan rel kereta api sebagai finishing lantai, dan finishing dinding sedangkan material kayu jati bekas bongkaran rumah lama diaplikasikan sebagai finishing plafon. Kayu yang diaplikasikan pada elemen interior restoran A semuanya dilapisi pewarna kayu transparan (sejenis politur). Pewarna kayu transparan diaplikasikan karena dapat mengekspos motif serat dan warna kayu untuk mendukung tema alami pada desain interior restoran A.

Kayu bekas yang diaplikasikan sebagai finishing plafon di restoran A terdapat dua jenis pola potongan kayu jati bekas (Gambar 2.a). Pola yang pertama adalah potongan kayu bekas dengan finishing kayu transparan berbentuk geometri persegi panjang yang bervariasi lebarnya disusun berjajar. Sedangkan pada pola kedua aplikasi kayu bekas di plafon gambar 2 (a) bentuk potongan kayunya adalah bangun segitiga yang digabungkan menjadi bentuk geometri persegi.

Kayu bekas yang diaplikasikan sebagai finishing dinding berada di belakang area meja kasir dan meja reservasi restoran (gambar 2.b). Kayu bekas yang diaplikasikan di belakang meja kasir adalah kayu bekas bantalan rel kereta api sedangkan pada area reservasi diaplikasikan kayu jati bekas yang diolah seperti aplikasi kayu bekas pada plafon di area reservasi dan restoran (gambar 2.b). Proses pengolahan kayu jati bekas yang diaplikasikan pada 
dinding area reservasi sama dengan yang diaplikasikan pada plafon area reservasi dan restoran. Pada aplikasi kayu bekas bantalan rel, pengolahannya hanya melalui pemotongan kayu sesuai ukuran yang diperlukan dan dibersihkan sebelum dilakukan dilapisi finishing. Kayu dengan permukaan bertekstur kasar digunakan sebagai finishing meja kasir, sedangkan potongan kayu yang permukaannya halus diaplikasikan sebagai material rak, finishing dinding dan lantai. Tekstur kasar serat kayu yang diekspos pada meja kasir untuk memperkuat kesan alami dan menjadi point of view di area kasir restoran A.

Material kayu bekas yang diaplikasikan sebagai material lantai adalah kayu bekas bantalan rel kereta api (gambar 2.c). Pengolahan kayu bekas bantalan rel kereta yang diaplikasikan pada lantai sama dengan pengolahan material kayu bekas bantalan rel yang diaplikasikan pada dinding area meja kasir.

\section{Strategi Aplikasi Material Kayu Bekas pada Restoran B}

Kayu bekas yang diaplikasikan untuk material pembentuk ruang adalah kayu bekas, daun jendela dan pintu kayu bekas berbentuk krepyak. Material daun jendela dan pintu kayu bekas berbentuk krepyak diaplikasikan sebagai plafon di area pintu masuk utama di lantai 1 dan di area restoran lantai 2 (gambar 3.a). Aplikasi material daun jendela dan pintu kayu bekas berbentuk krepyak sebagai plafon tidak melalui proses pengolahan. Daun jendela dan pintu kayu bekas berbentuk krepyak yang diaplikasikan sebagai plafon dipilih yang kondisi tampilannya masih utuh dan kualitas kekuatan kayunya masih bagus (tidak keropos karena serangga). Finishing sebelumnya pada material kayu bekas tersebut tetap dipertahankan, sehingga tidak dilakukan finishing ulang. Daun jendela dan pintu krepyak berbentuk persegi dibiarkan pada bentuk apa adanya, dan hanya dirapikan sisi-sisinya agar dapat digabungkan dengan lainnya.

Kayu bekas yang diaplikasikan pada dinding (gambar 3.b) sama dengan kayu bekas yang diaplikasikan pada plafon (gambar 3.a) di restoran B yaitu daun jendela dan pintu kayu bekas yang berbentuk krepyak tanpa finishing ulang. Perbedaannya, aplikasi kayu bekas berbentuk krepyak sebagai plafon penyusunannya horisontal, sedangkan pada finishing dinding disusun secara vertikal dan sama-sama menggunakan rangka untuk menyusunnya.

Aplikasi material kayu bekas sebagai finishing lantai terdapat di area restoran lantai 2. Luas penggunaan material kayu bekas sebagai material lantai hanya 25\% dari keseluruhan luas. Aplikasi lantai kayu hanya digunakan sebagai penanda area sirkulasi, area pertunjukan live music dan area tempat duduk kru pemusik (gambar 3.b). Kayu bekas di ampelas untuk menghaluskan permukaannya, kemudian dipotong- potong sesuai ukuran yang dibutuhkan untuk finishing lantai, dan kemudian kayu di-finishing politur.

\section{Klasifikasi Tingkat Strategi Aplikasi Material Kayu Bekas di Restoran A dan B dengan Metode Ukur DCBA}

Klasifikasi strategi aplikasi material bekas pada obyek studi ditinjau dari tingkatan kategori dalam DCBA. Analisis aplikasi material bekas pada obyek studi berdasarkan pengamatan lapangan, data literatur dan wawancara tidak terstruktur kepada manajer restoran. 
Tiara I.W. Primadani, Dwinita Larasati, Budi Isdianto

Kajian Strategi Aplikasi Material Kayu Bekas pada Elemen Desain Interior Restoran di Bandung

Tabel 2. Analisis Aplikasi Material Kayu Bekas di Restoran A dan B dengan Metode Ukur DCBA

\begin{tabular}{|c|c|c|}
\hline ASPEK & Restoran A & Restoran B \\
\hline \multicolumn{3}{|l|}{ PLAFON } \\
\hline $\begin{array}{l}\text { Pemilihan } \\
\text { Material }\end{array}$ & $\begin{array}{l}\text { Material kayu bekas dari bongkaran rumah lama } \\
\text { sebagai finishing plafon }\end{array}$ & $\begin{array}{l}\text { Material kayu bekas daun jendela dan pintu yang } \\
\text { berbentuk krepyak sebagai finishing plafon. }\end{array}$ \\
\hline Bahan Baku & $\begin{array}{l}\text { Material bekas, mengurangi penggunaan material A } \\
\text { baru. }\end{array}$ & $\begin{array}{l}\begin{array}{l}\text { Material bekas, mengurangi penggunaan material A } \\
\text { baru. }\end{array} \\
\end{array}$ \\
\hline Finishing & Menggunakan finishing waterbase & Tidak menggunakan finishing baru. \\
\hline $\begin{array}{l}\text { Lokasi } \\
\text { Material } \\
\text { Diperoleh }\end{array}$ & Material diperoleh dari Bandung dan sekitarnya. & $\begin{array}{l}\text { Material dikumpulkan dari pengepul kayu bekas di } \mathrm{C} \\
\text { pelosok Pulau Jawa. }\end{array}$ \\
\hline Pemasangan & Pemasangannya menggunakan paku dan lem. & Pemasangannya menggunakan paku. \\
\hline Perawatan & Menggunakan air sebagai bahan pembersih. & Menggunakan air sebagai bahan pembersih. \\
\hline $\begin{array}{l}\text { Akhir Masa } \\
\text { Pakai }\end{array}$ & $\begin{array}{l}\text { Kayu dapat digunakan kembali sebagai finishing A } \\
\text { plafon atau material elemen pembentuk ruang tanpa } \\
\text { di daur ulang. }\end{array}$ & $\begin{array}{l}\text { Kayu dapat digunakan kembali sebagai plafon atau } \\
\text { material elemen pembentuk ruang lainnya tanpa di } \\
\text { daur ulang. }\end{array}$ \\
\hline \multicolumn{3}{|r|}{ ( } \\
\hline $\begin{array}{l}\text { Pemilihan } \\
\text { Material }\end{array}$ & $\begin{array}{l}\text { Mengaplikasikan material kayu bekas pada sebagian } \\
\text { kecil finishing dinding. }\end{array}$ & $\begin{array}{ll}\text { Material kayu bekas daun jendela dan pintu yang } & \text { D } \\
\text { berbentuk krepyak sebagai finishing material dinding } & \text { / } \\
\text { di sebagian besar bagian. } & \text { C } \\
\end{array}$ \\
\hline Bahan Baku & $\begin{array}{l}\begin{array}{l}\text { Material bekas, mengurangi penggunaan material } \\
\text { baru. }\end{array} \\
\end{array}$ & $\begin{array}{l}\begin{array}{l}\text { Material bekas, mengurangi penggunaan material } \\
\text { baru. }\end{array} \\
\end{array}$ \\
\hline Finishing & Menggunakan finishing politur dan waterbase. & Tidak menggunakan finishing baru. \\
\hline $\begin{array}{l}\text { Lokasi } \\
\text { Material } \\
\text { Diperoleh }\end{array}$ & Material diperoleh dari Bandung dan sekitarnya. & $\begin{array}{l}\text { Material dikumpulkan dari pengepul kayu bekas di } \\
\text { pelosok Pulau Jawa. }\end{array}$ \\
\hline Pemasangan & Pemasangannya menggunakan lem dan paku. & Pemasangannya menggunakan paku. \\
\hline Perawatan & Menggunakan air sebagai bahan pembersih. & Menggunakan air sebagai bahan pembersih. \\
\hline $\begin{array}{l}\text { Akhir Masa } \\
\text { Pakai }\end{array}$ & $\begin{array}{l}\text { Kayu dapat digunakan kembali sebagai finishing } \mathrm{A} \\
\text { dinding tanpa didaur ulang. }\end{array}$ & $\begin{array}{l}\text { Kayu dapat digunakan kembali sebagai finishing } \\
\text { dinding atau material elemen pembentuk ruang tanpa } \\
\text { didaur ulang. }\end{array}$ \\
\hline \multicolumn{3}{|l|}{ LANTAI } \\
\hline $\begin{array}{l}\text { Pemilihan } \\
\text { Material }\end{array}$ & $\begin{array}{l}\text { Mengaplikasikan material kayu bekas bantalan rel } \\
\text { kereta api. }\end{array}$ & $\begin{array}{l}\text { Mengaplikasikan material kayu bekas pada sebagian } \\
\text { kecil finishing lantai. }\end{array}$ \\
\hline Bahan Baku & $\begin{array}{l}\text { Material bekas, mengurangi penggunaan material A } \\
\text { baru. }\end{array}$ & $\begin{array}{l}\text { Material bekas, mengurangi penggunaan material A } \\
\text { baru. }\end{array}$ \\
\hline Finishing & Menggunakan finishing politur dan waterbase. & Menggunakan finishing politur. \\
\hline $\begin{array}{l}\text { Lokasi } \\
\text { Material } \\
\text { Diperoleh } \\
\end{array}$ & Material diperoleh dari Bandung dan sekitarnya. & Material diperoleh dari Bandung dan sekitarnya. \\
\hline Pemasangan & Pemasangannya menggunakan paku. & Pemasangan menggunakan lem. \\
\hline Perawatan & Menggunakan air sebagai bahan pembersih. & Menggunakan air sebagai bahan pembersih. \\
\hline $\begin{array}{l}\text { Akhir Masa } \\
\text { Pakai }\end{array}$ & $\begin{array}{l}\text { Kayu dapat digunakan kembali sebagai lantai atau } \\
\text { material elemen pembentuk ruang lainnya tanpa di } \\
\text { daur ulang dahulu. }\end{array}$ & $\begin{array}{l}\text { Kayu dapat digunakan kembali sebagai lantai tanpa di A } \\
\text { daur ulang. }\end{array}$ \\
\hline
\end{tabular}

Sumber: Data Analisis Penulis (2019)

Berdasarkan analisa strategi aplikasi material bekas pada elemen pembentuk ruang pada obyek studi restoran di Bandung, berikut tingkat aplikasi material kayu bekas ditinjau berdasarkan siklus hidupnya menurut konsep desain eko-interior.

\begin{tabular}{|c|c|c|c|c|c|c|c|c|c|c|c|}
\hline ASPEK & $\begin{array}{l}\text { OBJEK } \\
\text { STUDI }\end{array}$ & $\begin{array}{c}\text { D } \\
\text { TERAPAN } \\
\text { UMUM }\end{array}$ & $\begin{array}{c}\text { C } \\
\text { UPAYA } \\
\text { RINGAN }\end{array}$ & $\begin{array}{c}\text { B } \\
\text { UPAYA } \\
\text { SITUASI IDEAL }\end{array}$ & $\begin{array}{c}\text { A } \\
\text { SITUASI IDEAL }\end{array}$ & ASPEK & $\begin{array}{l}\text { OBJEK } \\
\text { STUDI }\end{array}$ & $\begin{array}{c}\text { D } \\
\text { TERAPAN } \\
\text { UMUM } \\
\end{array}$ & $\begin{array}{c}\text { C } \\
\text { UPAYA } \\
\text { RINGAN }\end{array}$ & $\begin{array}{c}\text { B } \\
\text { UPAYA } \\
\text { SITUASI IDEAL }\end{array}$ & $\begin{array}{c}\text { A } \\
\text { SITUASI IDEAL }\end{array}$ \\
\hline \multicolumn{6}{|l|}{ PLAFON } & \multicolumn{6}{|l|}{ DINDING } \\
\hline $\begin{array}{l}\text { Pemilihan } \\
\text { Material }\end{array}$ & $A$ & & & & & $\begin{array}{l}\text { Pemilihan } \\
\text { Material }\end{array}$ & $A$ & & & & \\
\hline \multirow{2}{*}{ Bahan Baku } & $A$ & & & & & \multirow[t]{2}{*}{ Bahan Baku } & $A$ & & & & \\
\hline & $B$ & & & & & & $B$ & & & & \\
\hline \multirow{2}{*}{ Finishing } & $A$ & & & & & \multirow[t]{2}{*}{ Finishing } & $A$ & & & & \\
\hline & $B$ & & & & & & $B$ & & & & \\
\hline \multirow{2}{*}{ Pemasangan } & $A$ & & & & & \multirow[t]{2}{*}{ Pemasangan } & $A$ & & & & \\
\hline & $B$ & & & & & & $B$ & & & & \\
\hline \multirow{2}{*}{ Perawatan } & $A$ & & & & & \multirow[t]{2}{*}{ Perawatan } & $A$ & & & & \\
\hline & $B$ & & & & & & $B$ & & & & \\
\hline \multirow{2}{*}{$\begin{array}{l}\text { Akhir Masa } \\
\text { Pakai }\end{array}$} & $A$ & & & & & \multirow{2}{*}{$\begin{array}{l}\text { Akhir Masa } \\
\text { Pakai }\end{array}$} & $A$ & & & & \\
\hline & $B$ & & & & & & $B$ & & & & \\
\hline
\end{tabular}

Gambar 3.a. Klasifikasi Tingkat Pengukuran DCBA Aplikasi Material Kayu Bekas di Restoran A dan B Sumber: Primadani, TIW (2015) 


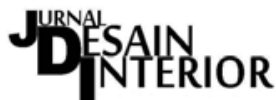

Vol. 4, No. 1, Juni 2019, pISSN 2527-2853, eISSN 2549-2985

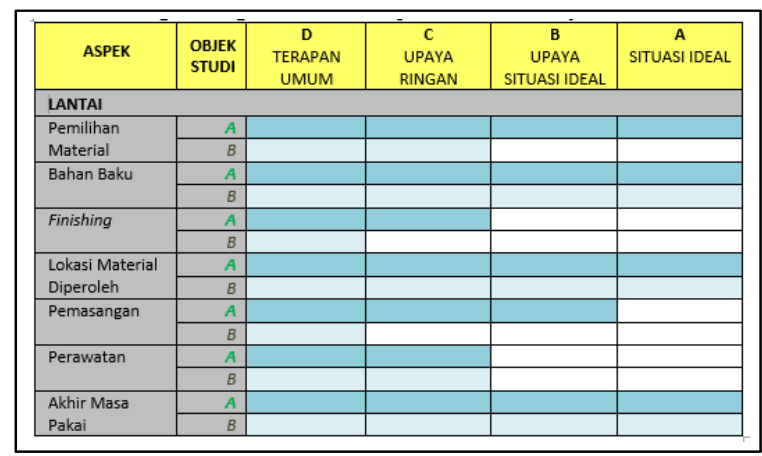

Gambar 3.b. Klasifikasi Tingkat Pengukuran DCBA Aplikasi Material Kayu Bekas di Restoran A dan B Sumber: Primadani, TIW (2015)

\section{KESIMPULAN}

Aplikasi kayu bekas pada elemen interior restoran menunjukkan bahwa material kayu bekas pun berpotensi menjadi bagian yang berperan penting dalam mencapai sebuah tema dalam suatu desain interior. Strategi aplikasi material bekas pada elemen interior tergantung pada tujuan aplikasinya oleh desainer, karena material bekas yang dihadirkan dalam desain interior akan menghasilkan tema dan suasana yang berbeda. Aplikasi material kayu bekas pada elemen interior restoran menunjukkan bahwa material kayu bekas mempunyai potensi untuk dikembangkan dengan memberikannya nilai tambah melalui kreativitas dan inovasi desain, sehingga menambah umur pakai suatu produk, mengurangi jumlah sampah dan mengurangi eksploitasi sumber daya alam.

Berdasarkan analisis strategi aplikasi material kayu bekas pada elemen interior restoran A dan restoran B, terdapat perbedaan strategi dalam menampilkan karakter material bekas. Material kayu dihadirkan di interior restoran A untuk menciptakan tema alami, sehingga warna kayu dan teksturnya terekspos. Kayu bekas yang diaplikasikan ke elemen interior restoran A di-finishing ulang agar material kayu terlihat baru dan memberi kesan 'bersih’ pada ruangan sebagai implementasi konsep gaya hidup sehat yang menjadi konsep toko restoran A. Pada restoran B aplikasi kayu bekas daun jendela/pintu berbentuk krepyak sengaja mempertahankan finishing dan kondisi asli material yang mana finishing aslinya yang warnanya sudah pudar dan sebagian catnya sudah terkelupas. Kesengajaan mengekspos kondisi asli material bekas bertujuan untuk mencapai tema desain interior urban industrial yang diusung restoran $\mathrm{B}$.

Aplikasi material kayu bekas pada elemen interior restoran A dan B bertujuan untuk mencapai tema desain interior restoran. Aplikasi material kayu bekas pada elemen interior restoran A berpedoman pada konsep eko-desain untuk mencapai tema desain interior "kembali ke alam (alami)", sedangkan aplikasi material kayu bekas pada elemen interior restoran B untuk mencapai tema urban industrial tanpa latar belakang konsep eko-desain. Perbedaan latar belakang tersebut mempengaruhi keputusan-keputusan yang diambil desainer dalam menentukan strategi aplikasi material kayu bekas pada elemen interior. Berdasarkan pengukuran tingkat terapan strategi aplikasi material bekas pada elemen interior restoran dengan metode DCBA yang ditinjau dari prinsip desain eko-interior, perbedaan pencapaian tingkat terapan eko-interior pada obyek studi tidak terlalu signifikan walaupun mempunyai perbedaan latar belakang aplikasinya. Tingkat terapan minimal aplikasi material kayu bekas pada elemen interior restoran A diukur dengan metode DCBA adalah "Upaya Ringan (C)" sedangkan di restoran B adalah "Terapan Umum (D)". Walaupun terdapat perbedaan latar belakang aplikasi material kayu bekas pada elemen interior obyek studi, namun sebagian besar 
Tiara I.W. Primadani, Dwinita Larasati, Budi Isdianto

Kajian Strategi Aplikasi Material Kayu Bekas pada Elemen Desain Interior Restoran di Bandung

pencapaian variabel ukur kedua obyek studi sama tingkatannya, hanya terdapat perbedaan yang juga tidak signifikan pada variabel aspek pemilihan material, finishing, lokasi material didapatkan dan pemasangannya.

Strategi dan tingkat aplikasi material bekas pada elemen interior restoran belum semuanya memenuhi situasi ideal desain eko-interior karena menyesuaikan dengan kondisi restoran yang merupakan bangunan komersial dan menjadi bagian dari gaya hidup masyarakat Indonesia saat ini. Strategi aplikasi material bekas pada elemen interior restoran tidak bisa mengabaikan faktor marketing dan bisnis yang melatarbelakangi restoran, sehingga strategi aplikasinya harus disesuaikan dengan kondisi masyarakat yang menjadi target konsumennya. Strategi aplikasi material bekas pada elemen interior restoran harus menarik perhatian pengunjung, bukan justru memberikan kesan yang negatif yang dapat berdampak pada kenyamanan pengunjung berada di dalam restoran tersebut. Untuk mendapat respon positif pengunjung, strategi penerapan material bekas pada elemen interior harus memperhatikan nilai estetikanya.

\section{DAFTAR PUSTAKA}

Aktas, G. G. (2013). Design Parameters and Initiatives for Ecological and Green Design in Interior Architecture. WSEAS Transactions on Environment and Development. Print ISSN: 1790-5079, E-ISSN: 2224-3496, Issue 1, Vol. 9, January 2013, hlm. 57-67.

Ayalp, N. (2012). Environmental Sustainability in Interior Design Elements. 7th WSEAS Conference on Energy and Environment (EE'12). July 13-17, hlm.163-167.

Bonda, P., \& Sosnowchik, K. (2007). Sustainable Commercial Interiors. USA: John Wiley and Sons.

Calkins, L. A. (2009). Materials for Sustainable Sites. New Jersey: John Willey and Sons, Inc.

Childs, K., Argeles, C., Henderson, H., Horst, S., \& Malin, N. (2006). Beyond Interior Design. (Online). (www.asid.org: http://www.asid.org/content/interior-design-and- globalimpacts\#.VEuVQvmUcn0, diakses pada 17 April 2014)

Falrisya, D. (2012). Penerapan Eco Style pada Bangunan Kontemporer. Tesis Magister Desain FRSD ITB, Bandung: ITB.

GBCI. (2014). Green Building Council Indonesia. (Online). (http://www.gbcindonesia.org/, 5 Oktober 2014)

Hidayat, J., \& Fatmahwaty. (2011). Reuse Material as Creative Strategy for Sustainable Design. International Conference on Creative Industry. Surabaya: Desain Produk Industri, Institut Teknologi Sepuluh Nopember.

Kang, M., \& Guerin, D.A. (2009). The State Enviromentally Sutainable Interior Design Practice. American Journal of Environmental Science 5 (2), 179-186.

Kusumarini, Y. (2007). Kajian Terapan Eko-Interior pada Bangunan Berwawasan Lingkungan. Tesis Magister Desain FRSD ITB, Bandung: ITB.

Kusumawidagdo, A. (2005). Peran penting Perancangan Interior pada Store Based Retail. Jurnal Dimensi Interior. Vol. 3, No.1, Juni 2005, hlm. 17-30.

Larasati, D. (2006). Towards an integral approach of sustainable housing in Indonesia: with an analysis of current practices in Java. (Online). (TU Delft Institutional Repository: http://repository.tudelft.nl/, 25 Maret 2014)

Lawson, F. (1973). Restaurant Planning \& Design. Britain: Architectural Press.

Maximillian, A. (2013). Korelasi Interior Restoran Italia dengan Restoran dan cafe Bergaya Italia di Kota Bandung. Tesis Magister Desain FRSD ITB, Bandung: ITB.

Pilatowicz, g. (1995). Eco-Interiors: a guide to environmentally conscious interior design. Canada: John Wiley \& Sons, Inc. 
Prabu Wardono, H. H. (2011). Effect Restaurant Interior Elements on Social Dining Behavior. Asian Journal of Environment-Behavior Studies, Vol.2, No.5, May 2011, chap 3.inddd 25.

Primadani, TIW. (2015). Kajian Desain Interior Restoran yang Mengaplikasikan Material Bekas Ditinjau dari Prinsip Desain Eko-Interior. Tesis Magister Desain FSRD ITB, Bandung : ITB.

Purnomo, A. (2013, 8 12). Tanah Teduh \#4. (Online). (Mamo Studio:http://mamostudio-bogorindonesia.blogspot.com/2013_08_01_archive.html, 3 Februari 2015) 
Tiara I.W. Primadani, Dwinita Larasati, Budi Isdianto

Kajian Strategi Aplikasi Material Kayu Bekas pada Elemen Desain Interior Restoran di Bandung 